\title{
Cytogenetic Characterization and Nuclear DNA Content of Diploid and Tetraploid Forms of Stokes Aster
}

\author{
Jessica Gaus Barb ${ }^{1,4}$ \\ Department of Horticultural Science, North Carolina State University, \\ Campus Box 7609, Raleigh, NC 27695-7609
}

Dennis J. Werner
Department of Horticultural Science, North Carolina State University,
Campus Box 7522, Raleigh, NC 27695-7522

Shyamalrau P. Tallury ${ }^{3}$

Crop Science Department, North Carolina State University, Greenhouse Unit 3, Campus Box 7629, Raleigh, NC 27695-7629

Additional index words. genomic downsizing, meiotic pairing, quadrivalents, bivalents, trivalents, disjunction, autotetraploid, karyotype, Stokesia laevis

\begin{abstract}
Stokesia laevis (J. Hill) Greene is a herbaceous perennial native to the southeastern United States. Most cultivars of Stokesia are diploid $(2 n=2 x=14)$ except for 'Omega Skyrocket', a tetraploid $(2 n=4 x=28)$ form selected from a natural population. A comparative study of the karyotypes and meiotic behavior of diploid cultivars, seed-derived accessions of 'Omega Skyrocket', synthetically derived autotetraploids, and triploid progeny from these taxa strongly suggest that 'Omega Skyrocket' is an autotetraploid form of Stokesia. Total karyotype length, $161 \mu \mathrm{m}$ and $293 \mu \mathrm{m}$, and average chromosome length, $11.5 \mu \mathrm{m}$ and $10.5 \mu \mathrm{m}$, of the diploid cultivars and tetraploid accessions of 'Omega Skyrocket', respectively, were determined. The karyotype of the diploid cultivars consisted of eight metacentric (m) and six submetacentric (sm) chromosomes with average arm ratio values ranging from 1.12 to 2.06 . The karyotype of 'Omega Skyrocket' consisted of $23 \mathrm{~m}$ chromosomes and $5 \mathrm{sm}$ chromosomes with average arm ratio values ranging from 1.22 to 2.02 . Meiotic pairing in the diploids was normal. No meiotic irregularities such as laggards or bridges were observed and disjunction was balanced (7:7). Accessions of 'Omega Skyrocket' demonstrated a high frequency $(60 \%)$ of quadrivalent formation; however, later stages of meiosis were regular with balanced disjunction (14:14) occurring in $95 \%$ of the cells. Meiotic configurations in synthetically derived autotetraploids and triploid hybrids from crosses of diploid cultivars $\times$ ' Omega Skyrocket' consisted of univalents, bivalents, trivalents, quadrivalents, and pentavalents. Abnormalities, including laggards, unequal and/or premature disjunction, chromosome bridges, and chromosome stickiness were observed. Average nuclear 2C DNA content was $20.3 \mathrm{pg}$ for the diploid cultivars and $39.9 \mathrm{pg}$ for the newly synthesized autotetraploids. Average nuclear 2C DNA content for 'Omega Skyrocket' was 37.3 pg, which was 8.2\% less than twice the average 2C DNA content of the diploid accessions and $6.4 \%$ less than the newly synthesized autotetraploids, suggesting that genomic downsizing in 'Omega Skyrocket' has occurred. Similarity of the karyotypes of the diploids and 'Omega Skyrocket' and the slight reduction in nuclear DNA content suggest that 'Omega Skyrocket' has diverged little from its original diploid progenitor.
\end{abstract}

Stokesia (J. Hill) Greene is a monotypic genus comprised of a single species (S. laevis) that is native to the coastal plain of the southeastern United States (i.e., Mississippi,

Received for publication 29 May 2008. Accepted for publication 26 Aug. 2008.

We gratefully acknowledge Layne Snelling and Janet Dow for their superb technical assistance.

${ }^{1}$ Graduate student. Current address: Center for Applied Genetic Technologies, University of Georgia, 111 Riverbend Road, Athens, GA 30602. ${ }^{2}$ Director, J.C. Raulston Arboretum.

${ }^{3}$ Senior Researcher.

${ }^{4}$ To whom reprint requests should be addressed; e-mail jgbarb@uga.edu
Louisiana, Alabama, Georgia, northern Florida, and South Carolina) (Bailey, 1949; Gunn and White, 1974). Stokesia is a member of the Vernonieae tribe (Asteraceae) that includes 121 genera and $\approx 1500$ species with global distribution (Robinson, 1999a, 1999b, 2007). There are 21 species of Vernonieae representing four genera (i.e., Vernonia Schreb., Stokesia, Elephantopus L., Pseudelephantopus Rohr) found in the southeastern United States with 19 of these being indigenous (Gunn and White, 1974; Jones, 1982). Stokesia is the only genus, however, that is restricted to the United States (Gettys and Werner, 2002; Jones, 1982).

Members of the Vernonieae tribe are extremely diverse in form, habitat, and ecol- ogy, indicating that this tribe has evolved and radiated over time. Examples of this diversity include the woody tree, Vernonia arborea Ham., which is the tallest species (greater than $30 \mathrm{~m}$ ) in the Asteraceae family and the small aquatic plant, Pacourina edulis Aubl., which has edible leaves. Additionally, there are a number of small acaulescent perennial taxa (e.g., Vernonia guineensis Benth., V. acrocephala Klatt, $V$. chthonocephala $\mathrm{O}$. Hoffm.) that thrive in fire-maintained savannahs in Africa (Jones, 1977, 1982). In general, members of the Vernonieae tribe are perennial, herbaceous plants, shrubs, small trees, or vines with alternate leaves showing pinnate venation. Flowers characteristically form large homogamous discoid heads with one to many perfect flowers that are deep purplish red to blue or sometimes white (Jones, 1982). Base chromosome number $(x)$ is highly variable in the Vernonieae tribe. New World taxa have a basic chromosome number of $x=8,10-19$ and often include many polyploid forms (e.g., $n=20,26-30$, 33-39, 51, 68) (Jones, 1977; Ruas et al., 1991). In contrast, most Old World taxa have a lower base number of 9 or 10 (Jones, 1977). Despite their overall diversity, all members of this tribe have uniquely shaped "Vernonioid" styles that are semicylindrical with acutely branched tips that present the hirsute surface of the stigma along the interior (Jones, 1982).

Stokesia has many of the essential features (e.g., perennial life cycle, alternate leaves, and "Vernonioid" style) that are typical of the Vernonieae tribe; however, floral and cytological characteristics of Stokesia are distinct. Specifically, Stokesia has zygomorphic flowers with ligulate ray florets that are deeply five-lobed and a reduced deciduous pappus, which are more characteristic of the Mutiseae and Lactuceae tribes (Jansen et al., 1991; Jones, 1977, 1982; Robinson, 1999c). Additionally, Stokesia has a low chromosome base number $(x=7)$ and large chromosomes, which are atypical of most Vernonieae (Gaus et al., 2005; Gunn and White, 1974; Jones, 1974). Despite these differences, Stokesia is consistently placed in the Vernonieae tribe (Jansen et al., 1991; Keeley et al., 2007; Keeley and Jansen, 1994; Kim et al., 1998; Kim and Jansen, 1995).

Stokesia is an attractive genus with large aster-like flowers that are characteristically pale blue or lavender in color with some cultivars having violet, pale yellow, pale pink, or albescent-colored flowers. Cultivars of Stokesia are 30 to $60 \mathrm{~cm}$ tall with many, moderately (three to five) branched flower scapes. Exceptions include 'Omega Skyrocket' [minimally (one to three) branched flower scapes greater than $1 \mathrm{~m}$ ] and 'Peachies Pick' [highly (five to seven) branched flower scapes 70 to $80 \mathrm{~cm}$ ] (Gettys and Werner, 2002).

'Omega Skyrocket' is an atypical example of stokes aster that was derived from a wild population discovered in Colquitt County, GA, near the town of Omega by R. Determann, S. Determann, and O. Johnson of 
the Atlanta Botanical Garden (Gettys and Werner, 2002). This natural population was uniform and consisted of plants with tall (greater than $1 \mathrm{~m}$ ), upright flower scapes. 'Omega Skyrocket' is primarily sold by seed; however, some clonal accessions are also available.

Preliminary work demonstrated that cultivars of Stokesia studied thus far are diploids $(2 n=2 x=14)$ except for 'Omega Skyrocket', which is a tetraploid form $(2 n=4 x=28)$ (Gaus et al., 2005). The cytological characteristics of mitosis and meiosis as well as an absolute genome size estimate for this species have not been described. The objectives of this work were to: 1) prepare a karyotype; 2) characterize the meiotic behavior of diploid, triploid, and tetraploid accessions of Stokesia laevis, including 'Omega Skyrocket'; and 3) determine the absolute nuclear 2C DNA content of diploid and tetraploid plants using flow cytometry.

\section{Materials and Methods}

Plant material. Diploid accessions of Stokesia ('Alba', 'Colorwheel', 'Honeysong Purple', 'Mary Gregory', 'Peach Melba', 'Peachies Pick', 'Purple Parasols') were acquired and maintained as asexually propagated clones with the exception of 'Alba', which was grown from true-to-type seed. Accessions of the naturally occurring tetraploid, 'Omega Skyrocket', were grown from seed acquired from Jelitto Seed Co. (Schwarmstedt, Germany). Triploid plants were produced by crossing 'Alba', 'Peach Melba', 'Peachies Pick', and 'Purple Parasols' with four different accessions of 'Omega Skyrocket'. Synthetic autotetraploid forms of diploid cultivars were produced using colchicine $[\mathrm{N}-(5,6,7,9$-tetrahydro- 1,2 , 3,10-tetra-methoxy-9-oxobenzo(a)heptalen7-yl)acetamide] or oryzalin (3,5-dinitro$N^{4} N^{4}$-dipropylsulfanilamide). Small $(2.5 \mathrm{~cm}$ diameter) asexually reproduced plantlets were fully submerged for 24 to $48 \mathrm{~h}$ in a saturated solution of $0.2 \%$ oryzalin, prepared by diluting $1 \mathrm{~mL}$ Surflan ${ }^{\circledR}$ A.S. (United Phosphorus Inc., Trenton, NJ) (40.4\% oryzalin) in $200 \mathrm{~mL}$ distilled water, or one to two drops $(\approx 250 \mu \mathrm{L})$ of $2.0 \%$ colchicine were applied twice daily (0800 HR, 1600 HR) directly to the meristematic whorl of each plantlet for $3 \mathrm{~d}$. Plants used for cytological examination were grown in sand under ambient light conditions in the greenhouses at North Carolina State University, Raleigh. Daytime temperatures in the greenhouse ranged from 25 to $35{ }^{\circ} \mathrm{C}$. Plants were fertilized daily with $100 \mathrm{mg} \cdot \mathrm{L}^{-1}$ nitrogen of Peters 20N-8.7P-16.6K General Purpose or Peters EXCEL Cal-Mag 15N-2.2P-12.5K fertilizer (The Scotts Co., Marysville, $\mathrm{OH}$ ).

Cytological techniques. Roots were collected between $1000 \mathrm{HR}$ and $1200 \mathrm{HR}$ on warm, sunny days. Roots were pretreated in a solution of $2 \mathrm{~mm} 8$-hydroxyquinoline plus colchicine $\left(0.5 \mathrm{~g} \cdot \mathrm{L}^{-1}\right)$ for 2 to $3 \mathrm{~h}$ at $4{ }^{\circ} \mathrm{C}$ (Dhesi and Stalker, 1994), fixed in freshly prepared Carnoy's solution (1 part glacial acetic acid: 3 parts chloroform: 6 parts $95 \%$ ethanol) for $48 \mathrm{~h}$ at room temperature (RT), and stored at $4{ }^{\circ} \mathrm{C}$ in $70 \%$ ethanol. Roots were hydrolyzed in $1 \mathrm{~N} \mathrm{HCl}$ at $60{ }^{\circ} \mathrm{C}$ for $8 \mathrm{~min}$, washed in distilled water, and stained in Schiff's reagent for a minimum of $30 \mathrm{~min}$ in the dark. Root tips were removed and squashed in $1 \%$ acetocarmine. Cells were observed using a light microscope (Carl Zeiss Photomicroscope 3; Carl Zeiss MicroImaging, Inc., Thornwood, NY) under $\times 630$ and $\times 1000$ magnification. Digital photographs of well-spread metaphase plates were taken using a Sony Cybershot F717 camera (Tokyo, Japan). Total karyotype length (TKL), the total length of individual chromosomes (TCL), and the length of the short (SA) and long (LA) arm of each chromosome were measured from digital photographs using MicroMeasure version 3.3 software (Reeves, 2001). Average chromosome length (ACL) and arm ratio (AR $=\mathrm{LA} / \mathrm{SA})$ were calculated from these measurements. Ideograms were constructed based on chromosome length and arm ratios. Chromosome nomenclature followed Levan et al. (1964) $(\mathrm{m}=$ metacentric, $\mathrm{sm}=$ submetacentric, $\mathrm{st}=$ subtelocentric). Intrachromosome asymmetry $\left(\mathrm{A}_{1}\right)$ was calculated following the formula $\mathrm{A}_{1}=1-\left[\Sigma\left(s_{i} / l_{i}\right) / n\right]$, where $s_{i}$ is the average length of the short arms in every chromosome, $l_{i}$ is the average length of the long arm of every chromosome, and $n$ is the number of chromosomes. This asymmetry index was adapted from the formula presented in Romero Zarco (1986), which calculated $A_{1}$ using measurements of homologous chromosome pairs, not individual chromosomes. Interchromosome asymmetry $\left(\mathrm{A}_{2}\right)$ was calculated following the formula $\mathrm{A}_{2}=\mathrm{sD} / x$, where SD is the standard deviation and $x$ is the mean of the chromosome lengths (Romero Zarco, 1986). The index of karyotype symmetry $\left(\mathrm{TF} \%=100 \Sigma \mathrm{S} \Sigma \mathrm{L}^{-1}\right)$ was also calculated (Huziwara, 1962).

Meiotic chromosomes were observed in developing pollen mother cells (PMCs). Immature buds ( 1 to $1.5 \mathrm{~cm}$ in diameter) were collected on bright sunny days between $0900 \mathrm{HR}$ and $1000 \mathrm{HR}$ and the sepals were removed. Buds were fixed in freshly prepared Carnoy's solution for $48 \mathrm{~h}$ at RT and stored in $70 \%$ ethanol at $4{ }^{\circ} \mathrm{C}$. Flower buds were dissected under a dissecting microscope and three to six anthers were removed and squashed in $1 \%$ acetocarmine. Cells were observed at $\times 630$ and $\times 1000$ magnification.

Nuclear DNA content determination. Absolute nuclear 2C DNA content was determined using a Becton-Dickinson FASCan flow cytometer (San Jose, CA) equipped with a 488-nm argon laser. Pisum sativum L. 'Citrad', with a known 2C DNA content of $8.76 \mathrm{pg}$ (Greilhuber et al., 2007), was used as an internal standard. Nuclei of the internal standard and sample were extracted and stained simultaneously according to protocols provided with the Partec CyStain PI Absolut P kit (Partec GmbH, Munster, Germany). Cold $\left(0{ }^{\circ} \mathrm{C}\right)$ extraction buffer $(500$ $\mu \mathrm{L}$ ) was added to $\approx 2 \mathrm{~cm}^{2}$ of newly expanded leaf tissue of the internal standard and sample and finely chopped for $30 \mathrm{~s}$ and incubated for $30 \mathrm{~s}$ at RT. The solution was filtered using Partec CellTrics ${ }^{\mathrm{TM}}$ disposable filters (Munster, Germany) with a pore size of $50 \mu \mathrm{m}$. Cold $\left(0^{\circ} \mathrm{C}\right)$ staining buffer $(1 \mathrm{~mL}$ staining buffer, $12 \mu \mathrm{L}$ of PI stock, $6 \mu \mathrm{L}$ RNase stock) was added and samples were incubated for $2 \mathrm{~h}$ at $4{ }^{\circ} \mathrm{C}$ protected from light before they were analyzed. Replications (four to five) over $2 \mathrm{~d}$ were analyzed for each plant with 5,000 to 10,000 nuclei analyzed per replication. Peaks used for analysis had coefficient of variation values of $6 \%$ or less. Conversion of mass values into number of base pairs (bps) was calculated using the factor $1 \mathrm{pg}=978 \mathrm{Mbp}$ (Doležel et al., 2003).

Statistical analysis. Data were subjected to analysis of variance using the PROC GLM procedure and means were separated by least significant difference $(P \leq 0.05)$ using SAS 9.1 software (SAS Institute, Cary, NC).

\section{Results}

Karyotype. Somatic chromosomes from seven diploid $(2 n=2 x=14)$ accessions ('Alba', 'Colorwheel', 'Honeysong Purple', 'Mary Gregory', 'Peach Melba', 'Peachies Pick', 'Purple Parasols') and three seedderived accessions of 'Omega Skyrocket' (OSR) $(2 n=4 x=28)$ were studied (Fig. 1). In all cases, chromosome counts were consistent with previous reports (Gaus et al., 2005; Gunn and White, 1974). There were few differences among the karyotypes of the
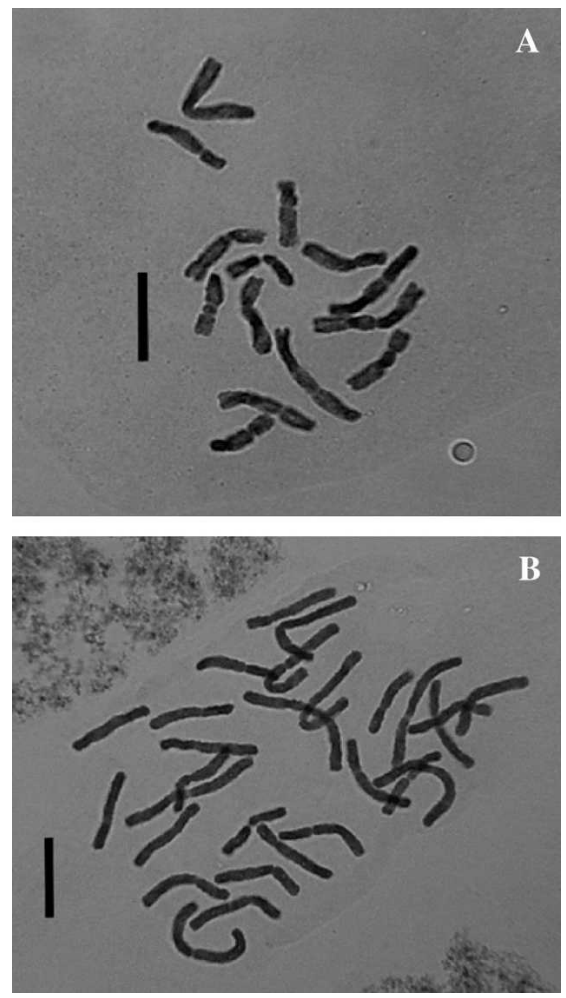

Fig. 1. Somatic chromosomes of Stokesia laevis (A) 'Peachies Pick' $(2 n=2 x=14)$ and (B) 'Omega Skyrocket' $(2 n=4 x=28)$. Scale bar $=$ $10 \mu \mathrm{m}$. 
diploid cultivars; thus, a single representative karyotype was constructed based on 33 well-spread metaphase plates (14, 'Honeysong Purple'; 14, 'Peachies Pick'; 5, 'Alba') (Fig. 2A). Similarly, there were few differences among the accessions of 'Omega Skyrocket', so one karyotype was constructed from 35 well-spread metaphase plates (14, OSR100; 15, OSR182; 6, OSR200) (Fig. 2B). Because chromosome morphology was very similar, individual chromosomes could not be definitively identified in all cases, thus preventing the direct comparison of chromosomes from the diploid accessions to the chromosomes of 'Omega Skyrocket'.

Average TKL for the four diploid accessions was $161 \pm 29 \mu \mathrm{m}$ with an ACL of $11.5 \pm$ $2.0 \mu \mathrm{m}$. Chromosomes ranged in length from $8.3 \mu \mathrm{m}$ to $16.1 \mu \mathrm{m}$ (Table 1 ). The average karyotype of the diploids consisted of eight metacentric $(\mathrm{m})$ chromosomes with average ARs ranging from 1.12 to 1.58 and six submetacentric $(\mathrm{sm})$ chromosomes with average ARs ranging from 1.72 to 2.06 (Table 1; Fig. 2). The average TKL was $293 \pm 53 \mu \mathrm{m}$ and ACL was $10.5 \pm 1.9 \mu \mathrm{m}$ for the three tetraploid accessions of 'Omega Skyrocket'. Chromosomes ranged in size from $7.3 \mu \mathrm{m}$ to $15.4 \mu \mathrm{m}$. The average karyotype of 'Omega Skyrocket' consisted of $23 \mathrm{~m}$ chromosomes with average ARs ranging from 1.22 to 1.68 and five sm chromosomes with average ARs ranging from 1.71 to 2.02 (Table 1; Fig. 2). The TKL $(293 \mu \mathrm{m})$ for 'Omega Skyrocket' was $\approx 9 \%$ less than two times the average TKL $(161 \times 2=322 \mu \mathrm{m})$ of the diploids. The overall symmetry of the karyotypes of 'Omega Skyrocket' and the diploid accessions were very similar. Karyotype symmetry (TF\%) was $66.68 \%$ and $67.93 \%$ for the diploids and 'Omega Skyrocket', respectively. Intrachromosome asymmetry $\left(\mathrm{A}_{1}\right)$ and interchromosome asymmetry $\left(\mathrm{A}_{2}\right)$ indices were 0.341 and 0.277 for the diploids and 0.328 and 0.289 for 'Omega Skyrocket', respectively.

Meiotic behavior. Meiosis was observed in PMCs of diploids, triploids, tetraploid accessions of 'Omega Skyrocket', and synthetic autotetraploids (Tables 2 and 3; Figs. 3-8). Chromosome pairing in the diploids was normal with each bivalent, usually possessing two chiasmata (Fig. 3). No meiotic irregularities such as laggards or bridges were observed and disjunction was equal (7:7) at later stages of meiosis. Average chromosome configuration of triploid taxa was $4.9 \mathrm{I}+5.2 \mathrm{II}+1.9 \mathrm{III}$ (Table 2). The most frequent configurations were $2 \mathrm{III}+5 \mathrm{II}+5 \mathrm{I}$, $3 \mathrm{III}+4 \mathrm{II}+4 \mathrm{I}$, and $1 \mathrm{III}+6 \mathrm{II}+6 \mathrm{I}$, which accounted for $25 \%, 19 \%$, and $18 \%$ of the cells, respectively (Fig. 4, data not shown). Lagging chromosomes (one to five) were present in either Anaphase I or Anaphase II in 53\% of the 34 PMCs observed (Fig. 5). Disjunction at Anaphase I and II in triploid cells without lagging chromosomes produced nearly balanced cells $(63 \%)$ with chromosome configurations of 10:11 and unbalanced configurations of 9:12 (31\%) and 8:13 (6\%), respectively (data not shown, Fig. 5). The
A

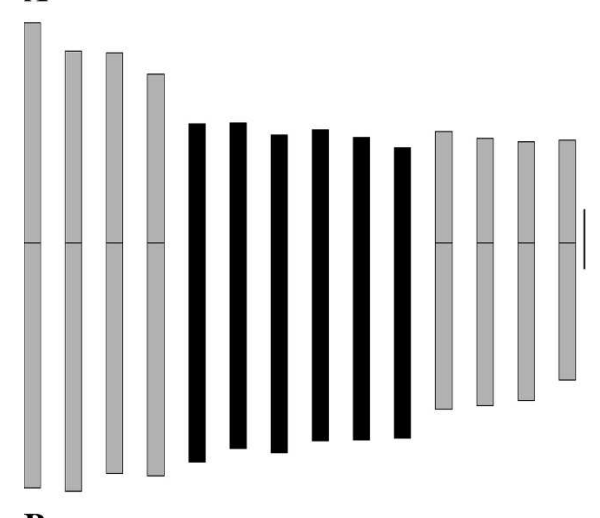

B

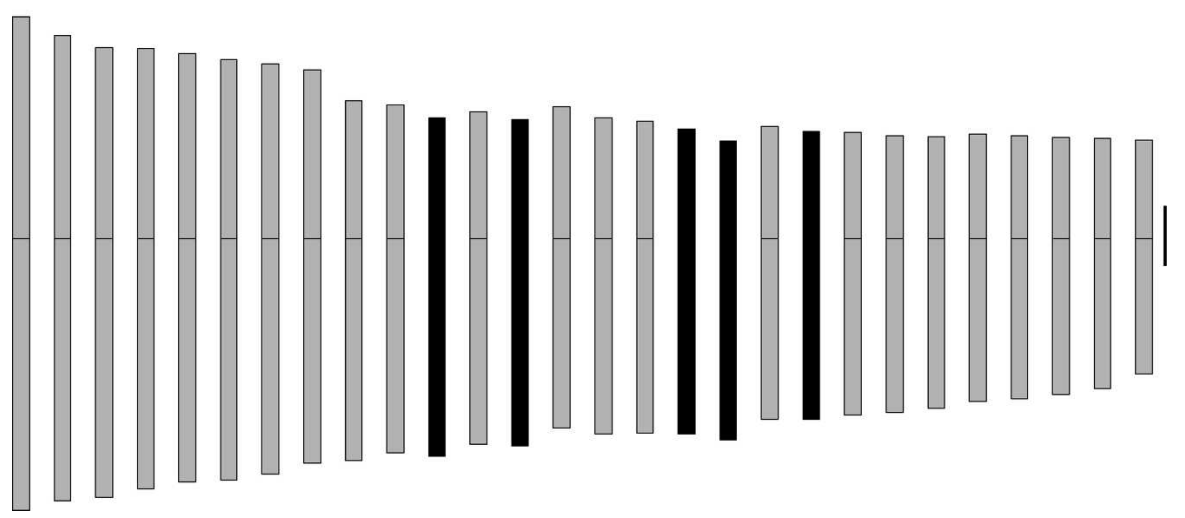

Fig. 2. Karyotype ideograms of Stokesia laevis. (A) Average karyotype of 'Honeysong Purple', 'Alba', 'Peachies Pick' $(2 n=2 x=14)$. (B) 'Omega Skyrocket' $(2 n=4 x=28)$. Metacentric chromosomes (AR $<1.7)$ in gray. Submetacentric chromosomes $(A R \geq 1.7)$ in black. Scale bar $=2 \mu \mathrm{m}$.

Table 1. Karyotypic parameters of Stokesia laevis.

\begin{tabular}{|c|c|c|c|c|c|c|c|}
\hline \multicolumn{4}{|c|}{ Arm ratio $^{z}$} & \multicolumn{4}{|c|}{ Chromosome length $(\mu \mathrm{m})^{\mathrm{y}}$} \\
\hline \multicolumn{2}{|c|}{ Diploid cultivars } & \multicolumn{2}{|c|}{ Omega Skyrocket } & \multicolumn{2}{|c|}{ Diploid cultivars } & \multicolumn{2}{|c|}{ Omega Skyrocket } \\
\hline $\bar{C} 1^{x}$ & $1.12 \pm 0.14$ & $\mathrm{C} 1$ & $1.22 \pm 0.17$ & $\mathrm{C} 1$ & $16.09 \pm 3.16$ & $\mathrm{C} 1$ & $15.37 \pm 3.42$ \\
\hline \multirow[t]{3}{*}{$\mathrm{C} 2$} & $1.30 \pm 0.20$ & $\mathrm{C} 2$ & $1.29 \pm 0.25$ & $\mathrm{C} 2$ & $15.22 \pm 2.67$ & $\mathrm{C} 2$ & $14.47 \pm 3.05$ \\
\hline & & $\mathrm{C} 3$ & $1.36 \pm 0.30$ & & & $\mathrm{C} 3$ & $14.01 \pm 2.83$ \\
\hline & & $\mathrm{C} 4$ & $1.31 \pm 0.22$ & & & $\mathrm{C} 4$ & $13.70 \pm 2.75$ \\
\hline $\mathrm{C} 3$ & $1.21 \pm 0.18$ & $\mathrm{C} 5$ & $1.31 \pm 0.21$ & $\mathrm{C} 3$ & $14.54 \pm 2.56$ & C5 & $13.34 \pm 2.65$ \\
\hline \multirow[t]{3}{*}{$\mathrm{C} 4$} & $1.39 \pm 0.16$ & C6 & $1.36 \pm 0.24$ & $\mathrm{C} 4$ & $13.89 \pm 2.54$ & C6 & $13.07 \pm 2.62$ \\
\hline & & C7 & $1.35 \pm 0.22$ & & & $\mathrm{C} 7$ & $12.76 \pm 2.50$ \\
\hline & & $\mathrm{C} 8$ & $1.33 \pm 0.21$ & & & $\mathrm{C} 8$ & $12.24 \pm 2.43$ \\
\hline $\mathrm{C} 5$ & $1.85 \pm 0.29$ & C9 & $1.60 \pm 0.30$ & $\mathrm{C} 5$ & $11.70 \pm 1.94$ & C9 & $11.21 \pm 2.35$ \\
\hline \multirow[t]{3}{*}{ C6 } & $1.72 \pm 0.24$ & $\mathrm{C} 10$ & $1.60 \pm 0.30$ & C6 & $11.26 \pm 1.97$ & $\mathrm{C} 10$ & $10.84 \pm 2.13$ \\
\hline & & $\mathrm{C} 11$ & $1.80 \pm 0.26$ & & & $\mathrm{C} 11$ & $10.53 \pm 2.01$ \\
\hline & & $\mathrm{C} 12$ & $1.63 \pm 0.24$ & & & $\mathrm{C} 12$ & $10.34 \pm 1.97$ \\
\hline C7 & $1.96 \pm 0.24$ & $\mathrm{C} 13$ & $1.75 \pm 0.25$ & C7 & $11.00 \pm 1.98$ & $\mathrm{C} 13$ & $10.15 \pm 1.91$ \\
\hline \multirow[t]{3}{*}{$\mathrm{C} 8$} & $1.76 \pm 0.29$ & $\mathrm{C} 14$ & $1.44 \pm 0.27$ & $\mathrm{C} 8$ & $10.76 \pm 1.93$ & $\mathrm{C} 14$ & $9.99 \pm 1.90$ \\
\hline & & $\mathrm{C} 15$ & $1.61 \pm 0.29$ & & & $\mathrm{C} 15$ & $9.85 \pm 1.85$ \\
\hline & & $\mathrm{C} 16$ & $1.66 \pm 0.36$ & & & $\mathrm{C} 16$ & $9.69 \pm 1.78$ \\
\hline C9 & $1.88 \pm 0.35$ & $\mathrm{C} 17$ & $1.78 \pm 0.40$ & C9 & $10.47 \pm 1.87$ & $\mathrm{C} 17$ & $9.51 \pm 1.77$ \\
\hline \multirow[t]{3}{*}{$\mathrm{C} 10$} & $2.06 \pm 0.33$ & $\mathrm{C} 18$ & $2.02 \pm 0.37$ & $\mathrm{C} 10$ & $10.06 \pm 1.90$ & $\mathrm{C} 18$ & $9.31 \pm 1.68$ \\
\hline & & $\mathrm{C} 19$ & $1.61 \pm 0.33$ & & & C19 & $9.12 \pm 1.66$ \\
\hline & & $\mathrm{C} 20$ & $1.71 \pm 0.32$ & & & $\mathrm{C} 20$ & $8.95 \pm 1.63$ \\
\hline C11 & $1.49 \pm 0.31$ & $\mathrm{C} 21$ & $1.66 \pm 0.29$ & $\mathrm{C} 11$ & $9.60 \pm 1.75$ & $\mathrm{C} 21$ & $8.81 \pm 1.59$ \\
\hline \multirow{3}{*}{$\mathrm{C} 12$} & $1.56 \pm 0.33$ & $\mathrm{C} 22$ & $1.68 \pm 0.54$ & $\mathrm{C} 12$ & $9.25 \pm 1.80$ & $\mathrm{C} 22$ & $8.60 \pm 1.51$ \\
\hline & & $\mathrm{C} 23$ & $1.66 \pm 0.38$ & & & $\mathrm{C} 23$ & $8.45 \pm 1.48$ \\
\hline & & $\mathrm{C} 24$ & $1.56 \pm 0.36$ & & & $\mathrm{C} 24$ & $8.33 \pm 1.48$ \\
\hline $\mathrm{C} 13$ & $1.58 \pm 0.29$ & $\mathrm{C} 25$ & $1.57 \pm 0.58$ & $\mathrm{C} 13$ & $8.95 \pm 1.72$ & $\mathrm{C} 25$ & $8.18 \pm 1.47$ \\
\hline \multirow[t]{3}{*}{ C14 } & $1.34 \pm 0.32$ & $\mathrm{C} 26$ & $1.55 \pm 0.31$ & C14 & $8.30 \pm 1.63$ & $\mathrm{C} 26$ & $8.01 \pm 1.47$ \\
\hline & & $\mathrm{C} 27$ & $1.50 \pm 0.33$ & & & $\mathrm{C} 27$ & $7.78 \pm 1.41$ \\
\hline & & $\mathrm{C} 28$ & $1.38 \pm 0.29$ & & & $\mathrm{C} 28$ & $7.28 \pm 1.35$ \\
\hline
\end{tabular}

${ }^{\mathrm{z}}$ Arm ratio $=$ length of long arm/length of short arm \pm SD.

y Value in $(\mu \mathrm{m}) \pm \mathrm{SD}$.

${ }^{\mathrm{x}}$ Chromosome number. 
Table 2. Chromosome associations in pollen microsporocytes of different cytotypes of Stokesia laevis.

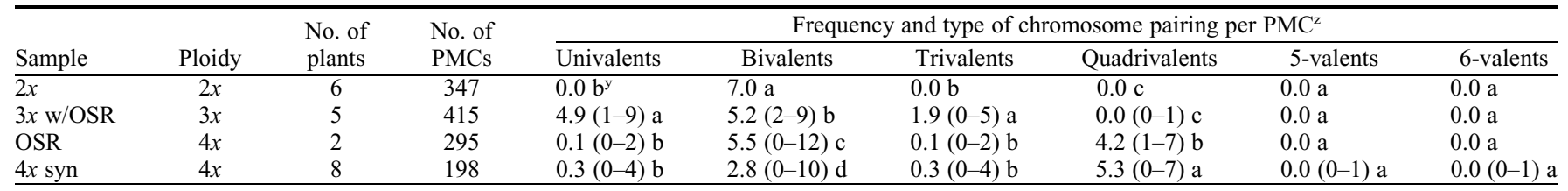

${ }^{\mathrm{z}}$ Values $=$ average (range).

${ }^{y}$ Values with different letters within a column are significantly different (least significant difference, $P<0.05$ ). Values were transformed before analysis to accommodate statistical comparisons across different ploidy levels.

$\mathrm{PMC}=$ pollen mother cell; $2 x=$ diploid cultivars; $3 x \mathrm{w} / \mathrm{OSR}=$ triploids produced from crosses of diploid cultivars $\times$ 'Omega Skyrocket'; OSR = 'Omega Skyrocket' accessions; $4 x$ syn $=$ synthetically derived tetraploids.

Table 3. Average nuclear DNA content of different Stokesia laevis as determined by flow cytometric measurements of PI-stained nuclei.

\begin{tabular}{llcrr}
\hline Sample & \multicolumn{4}{c}{ Avg nuclear DNA content } \\
$(2 \mathrm{C} / \mathrm{pg})^{\mathrm{z}}$ & $\mathrm{Mbp}^{\mathrm{y}}$ & $\mathrm{N}^{\mathrm{x}}$ \\
\hline $2 x$ & 14 & $20.3 \pm 0.1 \mathrm{c}^{\mathrm{w}}$ & 19,900 & 6 \\
OSR & 28 & $37.3 \pm 0.5 \mathrm{~b}$ & 36,500 & 5 \\
$4 x$ syn & 28 & $39.9 \pm 0.3 \mathrm{a}$ & 39,000 & 5 \\
\hline
\end{tabular}

${ }^{2}$ Mean \pm SE.

${ }^{\mathrm{y}}$ Conversion of mass values into number of bps was calculated using the factor $1 \mathrm{pg}=978 \mathrm{Mbp}$ (Doležel et al., 2003).

${ }^{\mathrm{x}}$ Number of plants with four to five replications tested per plant.

"Values with different letters are significantly different (least significant difference, $P \leq 0.05$ ).

$2 x=$ diploid cultivars; OSR $=$ seed derived accessions of 'Omega Skyrocket'; $4 x$ syn $=$ synthetically derived tetraploids; $\mathrm{Mbp}=$ megabase pair. average chromosome configuration of tetraploid accessions of 'Omega Skyrocket' was $0.1 \mathrm{I}+5.5 \mathrm{II}+0.1 \mathrm{III}+4.2 \mathrm{IV}$ (Table 2$)$. The most frequent configurations were $5 \mathrm{IV}+4 \mathrm{II}$ and $4 \mathrm{IV}+6 \mathrm{II}$, which accounted for $27 \%$ and $24 \%$ of the cells, respectively (Fig. 6 , data not shown). Equal disjunction (14:14) was observed in $95 \%$ of the 84 anaphase cells observed (Fig. 7A). The average chromosome configuration of the eight synthetic autotetraploids was $0.3 \mathrm{I}+2.8 \mathrm{II}+0.3 \mathrm{III}+$ 5.3IV (Table 2). The most common configurations were 7IV, 6IV + 2II, 5IV + 4II, and $4 \mathrm{IV}+6 \mathrm{II}$, which accounted for $25 \%, 22 \%$, not shown). Although laggards were observed in only one cell (Fig. 7B), only $38 \%$ of the 40 anaphase cells were equally

Bivalent frequency was significantly higher and quadrivalent frequency was signif-

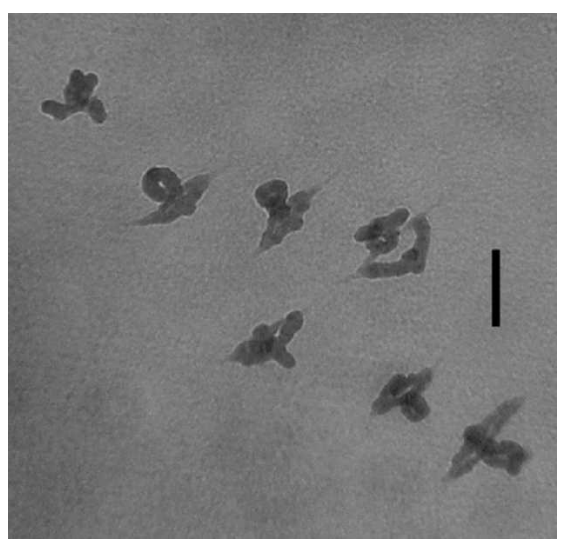

Fig. 3. Meiotic chromosome associations of diploid Stokesia laevis 'Peachies Pick', 7 ring bivalents at Metaphase I $(2 n=2 x=14)$. Scale bar $=$ $10 \mu \mathrm{m}$. $15 \%$, and $10 \%$ of the cells, respectively (data balanced (14:14) (data not shown). icantly lower $(P<0.05)$ in PMCs of 'Omega Skyrocket' relative to that observed in PMCs of the newly synthesized tetraploids (Table 2). Triploid taxa produced more $(P<0.05)$ univalents and trivalents than the other taxa.

Nuclear DNA content estimation. 2C nuclear DNA content was determined for six diploid accessions ('Alba', 'Colorwheel', 'Peachies Pick', 'Honeysong Purple', 'Purple Parasols', 'Peach Melba'), five accessions of 'Omega Skyrocket', and five synthetic autotetraploids ( $4 x$-'Alba', $4 x$-'Colorwheel', $4 x$-'Peachies Pick', $4 x$-'Purple Parasols', $4 x$ 'Peach Melba') (Table 3; Fig. 8). Chromosome number was confirmed for all of the diploids tested, three of the 'Omega Skyrocket' accessions, and all of the synthetic tetraploids except for $4 x$ - 'Peach Melba' (data not shown). There was no difference $(P<$ 0.001 ) between measurements taken on different days, so replications were pooled for analysis. Average 2C nuclear DNA content was significantly different across all groups $(P<0.001)$ (Table 3). Average 2C DNA content of the synthetic autotetraploids (39.9 \pm $0.3 \mathrm{pg}$ ) was approximately twice (196\%) the average $2 \mathrm{C}$ nuclear DNA content of the diploid accessions $(20.3 \pm 0.1 \mathrm{pg})$. Average 2C DNA content of the natural tetraploid
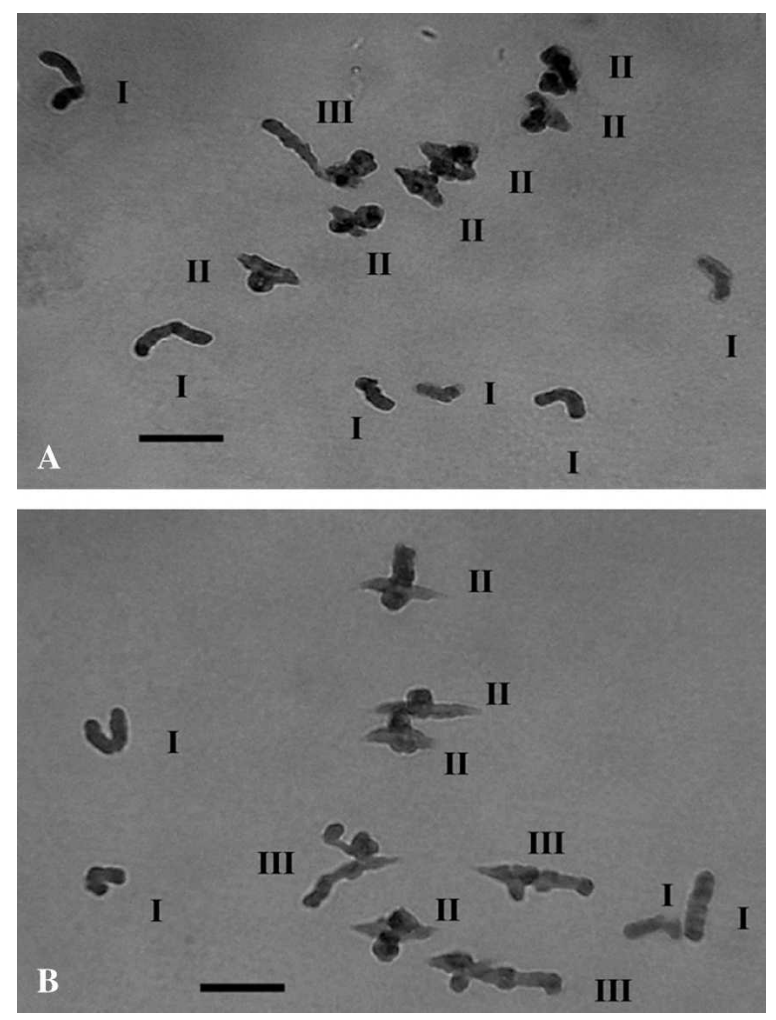

Fig. 4. Meiotic chromosome associations of triploid Stokesia laevis $(2 n=3 x=21)$. Scale bar $=10 \mu \mathrm{m}$. (A) 'Purple Parasols' $\times$ 'Omega Skyrocket'; 1 frying pan trivalent, 6 bivalents, 6 univalents at Metaphase I. (B) 'Peachies Pick' $\times$ 'Omega Skyrocket'; 3 trivalents (2 frying pans +1 Y-shape), 4 bivalents, 4 univalents at Metaphase I. 

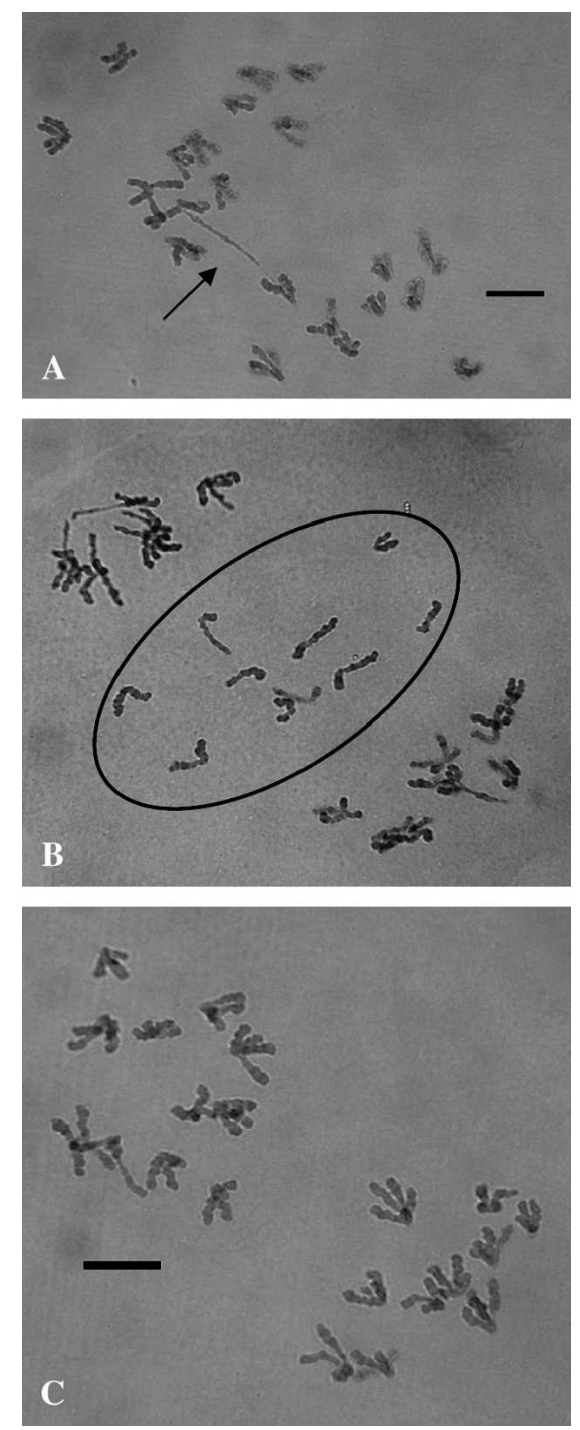

Fig. 5. Meiotic chromosome abnormalities observed in triploid hybrids of Stokesia laevis $(2 n=3 x=21)$. Scale bar $=10 \mu \mathrm{m}$. (A) 'Peachies Pick' $\times$ 'Omega Skyrocket' with unbalanced balanced disjunction (12:9) at Anaphase I; arrow indicates possible chromosome bridge. (B) 'Peachies Pick' $\times$ 'Omega Skyrocket' with 10 laggards (circled) at Anaphase I. (C) 'Purple Parasols' $\times$ 'Omega Skyrocket', unbalanced disjunction (10:11) at Anaphase I.

accessions of 'Omega Skyrocket' $(37.3 \pm 0.5$ $\mathrm{pg}$ ) was $\approx 6.4 \%$ less than the synthetic autotetraploids and $8.2 \%$ less than twice the average $2 \mathrm{C}$ DNA content of the diploid accessions. The basic monoploid genome size $\left(1 \mathrm{C}_{\mathrm{x}}\right)$ for the diploids, 'Omega Skyrocket', and the synthetic tetraploids was $10.2 \mathrm{pg}, 9.3 \mathrm{pg}$, and $10.0 \mathrm{pg}$, respectively. All accessions had an intermediate-sized genome (i.e., $3.5 \mathrm{pg}<1 \mathrm{C}_{\mathrm{x}}>14.0 \mathrm{pg}$ ) (Leitch et al., 2005).

\section{Discussion}

All members of the Vernonieae tribe classified thus far from India and North, South, and Central America, including Stokesia, have chromosomes that are fairly symmetrical and classified mainly as either
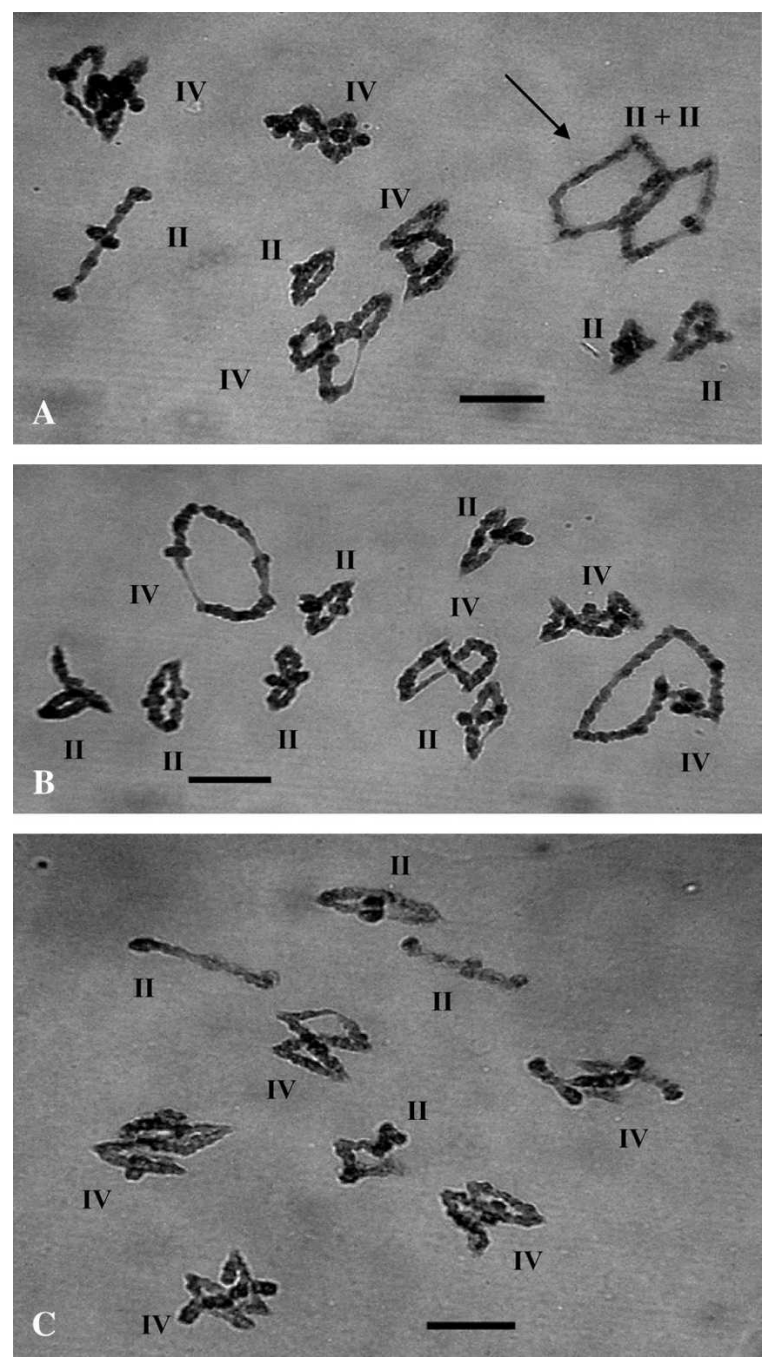

Fig. 6. Meiotic chromosome associations of Stokesia laevis 'Omega Skyrocket' $(2 n=4 x=28)$. Scale bar $=$ $10 \mu \mathrm{m}$. Metaphase I configurations. (A) Four figure-8 quadrivalents and six bivalents; arrow indicates interlocking bivalents. (B) Four quadrivalents (2 figure-8s, 2 rings) and 6 bivalents. (C) Five quadrivalents (all figure- $8 \mathrm{~s}$ ) and 4 bivalents ( 2 rings +2 rods).

metacentric or submetacentric (Dematteis, 1998, 2002; Dematteis and Fernández, 1998; De Oliveira et al., 2007; Esteves Mansanares et al., 2007; Mathew and Mathew, 1983; Ruas et al., 1991; Smith and Jones, 1987). The TCLs of Stokesia (i.e., 8 to $16 \mu \mathrm{m})$, however, were significantly greater than that observed for any of the other Vernonieae species (i.e., 1 to $4 \mu \mathrm{m})$. Stokesia also differs from other species in the tribe because it has an unusually low base chromosome number of $x=7$, which is only present in Vernonia appendiculata Less., a species native to Madagascar (Rabakonandrianina and Carr, 1987). Stokesia is a New World species but it shares a low base chromosome number $(x)$ that is more typical of an Old World species of the Vernonieae tribe (i.e., $x=9,10$ ). This is not surprising, however, because phylogenetic studies using chloroplast DNA restriction site data and sequence data from the chloroplast, $n d h \mathrm{~F}$ gene, noncoding spacer trnL-F, and the nuclear rRNA ITS region illustrate that New and Old World species of the Vernonieae tribe are not mutually exclusive
(Keeley and Jansen, 1994), and Stokesia in particular is often associated with Old World species despite its New World origin (Keeley et al., 2007).

Similarities between the karyotypes of the diploid cultivars and 'Omega Skyrocket' and the high frequency $(60 \%)$ of quadrivalent formation in 'Omega Skyrocket' both indicate that 'Omega Skyrocket' is an autotetraploid form of Stokesia laevis (Tables 1 and 2; Figs. 2 and 6). In theory, autotetraploids exhibiting a high frequency of quadrivalents are expected to have unequal chromosomal disjunction during later stages of meiosis resulting in a corresponding reduction in fertility. Studies show that selection over several generations for increased seed set in autotetraploid populations is associated with a decrease in quadrivalent frequency and a corresponding increase in mean bivalent frequency (Bremer and Bremer-Reinders, 1954; Hilpert, 1957; Kumar et al., 1993; Swaminathan and Sulbha, 1959). However, in other studies, selection for increased seed set in autotetraploid populations is correlated with an unexpected increase in the 

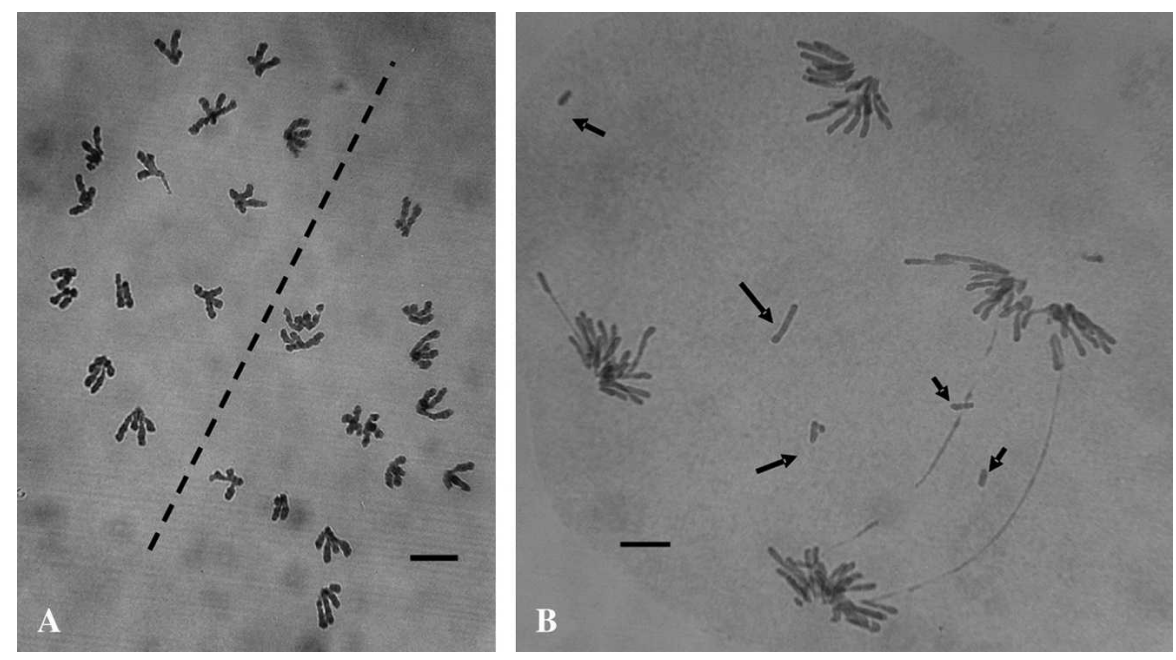

Fig. 7. Meiotic chromosome associations of tetraploids of Stokesia laevis $(2 n=4 x=28)$. Scale bar $=10 \mu \mathrm{m}$. (A) Anaphase I of 'Omega Skyrocket'; equal disjunction (14:14); dotted line indicates division line. (B) Telophase II of 4x-'Peach Melba'; lagging chromosomes indicated by arrows.

quadrivalent frequency and a corresponding decrease in univalent and trivalent frequencies (Crowley and Rees, 1968; Hazarika and Rees, 1967; McCollum, 1958; Narasinga Rao and Pantulu, 1982). In Stokesia, the high frequency $(60 \%)$ of quadrivalent formation in the autotetraploid accessions of 'Omega Skyrocket' did not result in a correspondingly high frequency of unequal disjunction and a reduction in fertility. In fact, later stages of meiosis in these accessions were regular and produced equally balanced gametes $95 \%$ of the time. Furthermore, the relatively high pollen viability (74\%) of 'Omega Skyrocket' (unpublished data) is further evidence that quadrivalent formation does not affect fertility in this taxa.

In the synthetically derived autotetraploids, $76 \%$ of the chromosomes were involved in quadrivalent formation, a slight but significant increase relative to 'Omega Skyrocket', which is a more established autotetraploid form. This observation was not surprising because quadrivalent frequency in newly synthesized autopolyploids often decreases over subsequent generations after the initial polyploidization event (Gilles and Randolph, 1951; Santos et al., 2003). Later stages of meiosis in the synthetic autotetraploids were irregular and unequal disjunction and chromosome stickiness were observed in a high percentage of cells, unlike 'Omega Skyrocket' in which meiosis was normal. The disparity between these two groups of tetraploids may be attributed, in part, to the "types" (e.g., ring, box, zigzag chain, figure-eight) of quadrivalents formed by each group (Figs. 6 and 8). Quadrivalents of 'Omega Skyrocket' were primarily figureeight types or zigzag chains with alternately oriented centromeres (data not shown) that presumably produced balanced $2 \times 2$ disjunction at Anaphase. In contrast, quadrivalents of the synthetic autotetraploids included zigzag chains and figure-eight types as well as rings with adjacently oriented centromeres and indifferently oriented configurations that presumably resulted in unbalanced disjunction in some of the cells.

Triploids from crosses of diploid cultivars $\times$ 'Omega Skyrocket' had more $(P \leq 0.05)$ univalents and trivalents (Table 2), which likely contributed to the formation of a high number of unbalanced gametes. Interestingly, an average chromosome configuration of $1.9 \mathrm{III}+5.2 \mathrm{II}+4.9 \mathrm{I}$ observed for the triploids suggests that chromosomal homology between 'Omega Skyrocket' and the diploids was similar enough to support trivalent formation but not similar enough to prevent the formation of a relatively high number of univalents. These results indicate that some genomic rearrangement in 'Omega Skyrocket' has probably occurred since the initial doubling event; however, enough chromosomal affinity still remains between 'Omega Skyrocket' and the diploid cultivars such that chromosomal pairing still occurs in the triploid hybrids.

The $\approx 9 \%$ reduction in TKL in 'Omega Skyrocket' relative to twice the karyotype of the diploids and the corresponding reduction in nuclear DNA content indicate that TKL and nuclear DNA content for this species are closely correlated, a trend frequently observed in other species (Cerbah et al., 1995; Dimitrova and Greilhuber, 2000; Garnatje et al., 2004; Moscone et al., 2003; Srivastava and Lavania, 1991; Torrell and Vallès, 2001). The reduction in nuclear DNA content and corresponding reduction in TKL indicate that differences in TKL between the diploids and 'Omega Skyrocket' is likely attributable to actual genomic downsizing and not an artifact of different chromosome condensation. Genomic downsizing in polyploid plants is a widespread phenomenon in which the monoploid genome size (i.e., $1 \mathrm{C}_{\mathrm{x}}=$ 2C DNA content divided by ploidy level; Greilhuber et al., 2005) decreases with increasing ploidy level (Leitch and Bennett, 2004). In this study, the monoploid genome size of 'Omega Skyrocket' (9.3 pg) was less than the basic genome size of the diploid
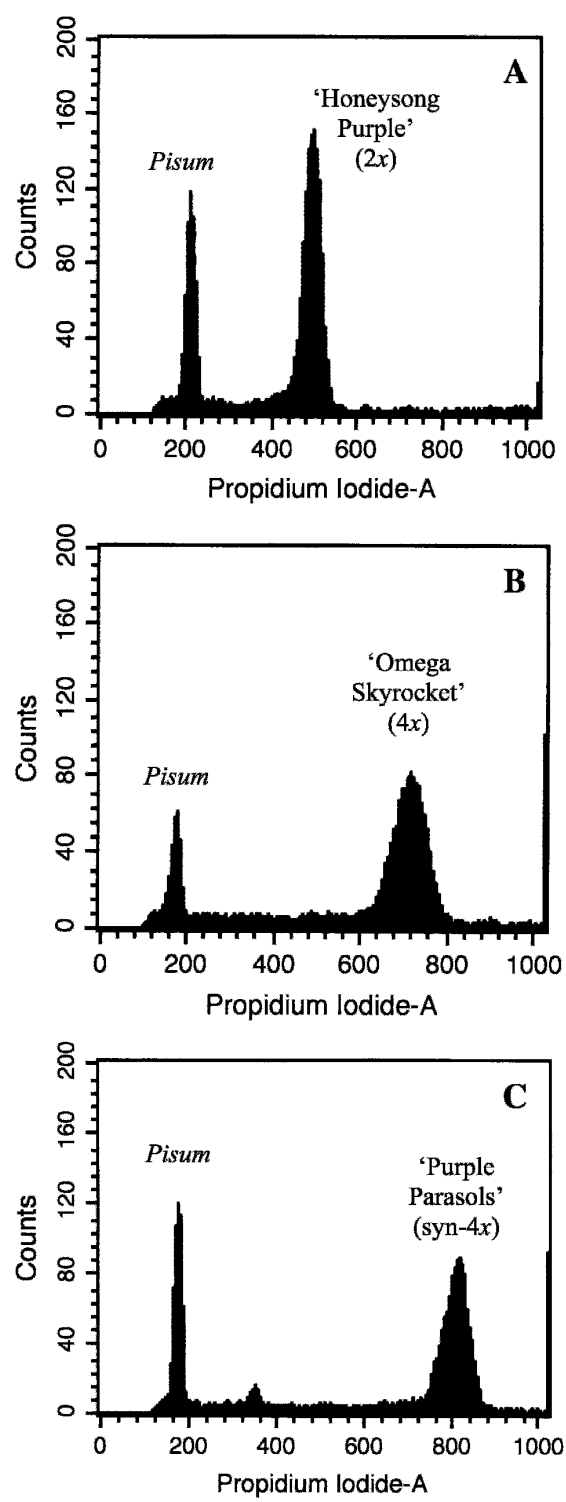

Fig. 8. Flow cytometry histograms of different cytotypes of Stokesia laevis. Pisum sativum L. 'Citrad' is the internal standard. (A) 'Honeysong Purple' $(2 n=2 x=14)$. (B) 'Omega Skyrocket' accession 100; naturally occurring tetraploid $(2 n=4 x=28)$. (C) $4 x$-'Purple Parasols'; synthetic autotetraploid $(2 n=4 x=28)$.

accessions (10.2 pg). Genomic downsizing of similar magnitude has been identified in other polyploids (Bennett et al., 2000; Emshwiller, 2002; Hörandl and Greilhuber, 2002; Pecinka et al., 2006; Raina et al., 1994).

According to Rees (1984), changes in DNA content (not attributable to aneuploidy or chromosome arm loss) can occur in two ways, whereby change is either proportional to chromosome size (Brandham and Doherty, 1998; Naranjo et al., 1998; Poggio et al., 2007) or change is achieved by the equal addition or subtraction of DNA to each chromosome irrespective of chromosome size (Pringle and Murray, 1993; Raina et al., 1994; Raina and Rees, 1983). Chromosomes of Stokesia are morphologically very similar preventing the definitive identification of individual chromosomes; thus, comparison 
of homologous chromosome pairs in the diploids to the homologous chromosome pairs in 'Omega Skyrocket' was not possible. However, if the chromosomes were grouped into homologous pairs according to TCL only and compared, the reduction in DNA in 'Omega Skyrocket' appeared to be proportionally distributed relative to chromosome length such that longer chromosomes lost more DNA than shorter chromosomes (data not shown).

Mechanisms capable of reducing genome size in plants include unequal and illegitimate recombination of retroelement sequences, inefficient double-stranded DNA break repair systems, mutational bias of deletions over insertions, and the targeted elimination of specific DNA sequences (e.g., rDNA) (reviewed in Bennett and Leitch, 2005; Bennetzen, 2002; Bennetzen et al., 2005; Petrov, 2001; Tate et al., 2005; Wendel, 2000; Wendel et al., 2002). Rapid genomic rearrangement (e.g., elimination of repetitive DNA, loss of amplified fragment length polymorphism and random amplified polymorphic DNAbands) in nascent allo- and autopolyploids has been identified in Brassica L. and Aegilops L. hybrids (Ozkan et al., 2001; Shaked et al., 2001; Song et al., 1995) and in autotetraploids of Paspalum L. and Eragrostis Host (Martelotto et al., 2007; Mecchia et al., 2007). These studies demonstrate that genomic rearrangement, and possibly genomic downsizing, in polyploids can occur immediately after an allo- or autopolyploidization event.

\section{Literature Cited}

Bailey, L.H. 1949. Manual of cultivated plants. Revised ed. Macmillian, New York, NY.

Bennett, M.D., P. Bhandol, and I.J. Leitch. 2000. Nuclear DNA amounts in angiosperms and their modern uses-807 new estimates. Ann. Bot. (Lond.) 86:859-909.

Bennett, M.D. and I.J. Leitch. 2005. Genome size evolution in plants, p. 90-151. In: Gregory, T.R. (ed.). The evolution of the genome. Elsevier, Amsterdam, The Netherlands.

Bennetzen, J.L. 2002. Mechanisms and rates of genome expansion and contraction in flowering plants. Genetica 115:29-36.

Bennetzen, J.L., J. Ma, and K.M. Devos. 2005. Mechanisms of recent genome size variation in flowering plants. Ann. Bot. (Lond.) 95:127132.

Brandham, P.E. and M.J. Doherty. 1998. Genome size variation in the Aloaceae, an angiosperm family displaying karyotypic orthoselection. Ann. Bot. Suppl. A:67-73.

Bremer, G. and D.E. Bremer-Reinders. 1954. Breeding of tetraploid rye in The Netherlands: Methods and cytological investigations. Euphytica 3:49-63.

Cerbah, M., J. Coulaud, B. Godelle, and S. SiljakYakovlev. 1995. Genome size, fluorochrome banding, and karyotype evolution in some Hypochoeris species. Genome 38:689-695.

Crowley, J.G. and H. Rees. 1968. Fertility and selection in tetraploid Lolium. Chromosoma 24:300-308

Dematteis, M. 1998. Karyotype analysis in some Vernonia species (Asteraceae) from South America. Caryologia 51:279-288.
Dematteis, M. 2002. Cytotaxonomic analysis of South American species of Vernonia (Vernonieae: Asteraceae). Bot. J. Linn. Soc. 139:401408.

Dematteis, M. and A. Fernández. 1998. Karyotypes of seven South American species of Vernonia (Asteraceae). Cytologia (Tokyo) 63:323328.

De Oliveira, V.M., E.R. Forni-Martins, and J. Semir. 2007. Cytotaxonomy or species of Vernonia, section Lepidaploa, group Axilliflorae (Asteraceae: Vernonieae). Bot. J. Linn. Soc. 154:99-108.

Dhesi, J.S. and H.T. Stalker. 1994. Enhancing techniques for studying mitotic peanut chromosomes. Peanut Sci. 21:92-94.

Dimitrova, D. and J. Greilhuber. 2000. Karyotype and DNA-content evolution in ten species of Crepis (Asteraceae) distributed in Bulgaria. Bot. J. Linn. Soc. 132:281-297.

Doležel, J., J. Bartoš, H. Volgmayr, and J. Greilhuber 2003. Nuclear DNA content and genome size of trout and human. Cytometry 51:127-128.

Emshwiller, E. 2002. Ploidy levels among species in the 'Oxalis turberosa Alliance' as inferred by flow cytometry. Ann. Bot. (Lond.) 89:741753.

Esteves Mansanares, M., E.R. Forni-Martins, and J. Semir. 2007. Cytotaxonomy of Lychnophoriopsis Sch. Bip. and Paralychnophora MacLeish species (Asteraceae: Vernonieae: Lychnophorinae). Bot. J. Linn. Soc. 154:109114.

Garnatje, T., J. Vallès, S. Garcia, O. Hidalgo, M. Sanz, M.A. Canela, and S. Siljak-Yakovlev. 2004. Genome size in Echinops L. and related genera (Asteraceae, Cardueae): Karyological, ecological and phylogenetic implications. Biocell 96:117-124.

Gaus, J., D. Werner, and S. Tallury. 2005. Polyploidy in stokes aster (Stokesia laevis). HortScience 40:1101 (abstr.).

Gettys, L.A. and D.J. Werner. 2002. Stokes aster. HortTechnology 12:138-142.

Gilles, A. and L.F. Randolph. 1951. Reduction in quadrivalent frequency in autotetraploid maize during a period of 10 years. Amer. J. Bot. 38:12-17.

Greilhuber, J., J. Doležel, M.A. Lysák, and M.D. Bennett. 2005. The origin, evolution and proposed stabilization of the terms 'genome size' and 'C-value' to describe nuclear DNA contents. Ann. Bot. (Lond.) 95:255-260.

Greilhuber, J., E.M. Temsch, and J.C.M. Loureiro. 2007. Nuclear DNA content measurement. In Doležel, J., J. Greilhuber, and J. Suda (eds.). Flow cytometry with plant cells. WILEY-VCH Verlag GmbH \& Co. KGaA, Weinheim, Germany.

Gunn, C.R. and G.A. White. 1974. Stokesia laevis. Taxonomy and economic value. Econ. Bot. 28:130-135.

Hazarika, M.H. and H. Rees. 1967. Genotypic control of chromosome behavior in rye. X. Chromosome pairing and fertility in autotetraploids. Heredity 22:317-332.

Hilpert, G. 1957. Effect of selection for meiotic behavior in auto-tetraploid rye. Hereditas 43:318-322.

Hörandl, E. and J. Greilhuber. 2002. Diploid and autotetraploid sexuals and their relationships to apomicts in the Ranunculus cassubicus group: Insights from DNA content and isozyme variation. Plant Syst. Evol. 234:85-100.

Huziwara, Y. 1962. Karyotype analysis in some genera of Compositae. VIII. Further studies on the chromosomes of Aster. Amer. J. Bot. $49: 116-119$
Jansen, R.K., H.J. Michaels, and J.D. Palmer. 1991 Phylogeny and character evolution in the Asteraceae based on chloroplast DNA restriction site mapping. Syst. Bot. 16:98-115.

Jones, S.B. 1974. Vernonieae (Compositae) chromosome numbers. Bull. Torrey Bot. Club 101:31-34.

Jones, S.B. 1977. Vernonieae-Systematic review. In: Heywood, V.H., J.B. Harborne, and B.L. Turner (eds.). The biology and chemistry of the Compositae, Vol. 1. Academic Press, London, UK.

Jones, S.B. 1982. The genera of Vernonieae (Compositae) in the southeastern United States. J. Arnold Arbor. 63:489-507.

Keeley, S.C., Z.H. Forsman, and R. Chan. 2007. A phylogeny of the 'evil tribe' (Vernonieae: Compositae) reveals Old/New World long distance dispersal: Support from separate and combined congruent datasets $(\operatorname{trn} \mathrm{L}-\mathrm{F}, n d h \mathrm{~F}$, ITS). Mol. Phylogenet. Evol. 44:89-103.

Keeley, S.C. and R.K. Jansen. 1994. Chloroplast DNA restriction site variation in the Vernonieae (Asteraceae), an initial appraisal of the relationship of New and Old World taxa and the monophyly of Vernonia. Plant Syst. Evol. 193:249-265.

Kim, H.-G., S.C. Keeley, P.S. Vroom, and R.K. Jansen. 1998. Molecular evidence for an African origin of the Hawaiian endemic Hesperomannia (Asteraceae). Proc. Natl. Acad. Sci. USA 95:15440-15445.

Kim, K.-J. and R.K. Jansen. 1995. $n d h \mathrm{~F}$ sequence evolution and the major clades in the sunflower family. Proc. Natl. Acad. Sci. USA 92:10379_ 10383.

Kumar, H., V.C. Mercykutty, and C.P. Srivastava. 1993. Fertility improvement in autotetraploids of pea-Selection for seed-set and disjunction index. Plant Breeding 110:81-83.

Leitch, I.J. and M.D. Bennett. 2004. Genome downsizing in polyploid plants. Biol. J. Linnean Soc. 82:651-663.

Leitch, I.J., D.E. Soltis, P.S. Soltis, and M.D Bennett. 2005. Evolution of DNA amounts across land plants (Embryophyta). Ann. Bot. (Lond.) 95:207-215.

Levan, A., K. Fredga, and A.A. Sandberg. 1964. Nomenclature for centromeric position on chromosomes. Hereditas 52:201-220.

Martelotto, L.G., J.P.A. Ortiz, J. Stein, F. Espinoza, C.L. Quarin, and S.C. Pessino. 2007. Genome rearrangements derived from autopolyploidization in Paspalum sp. Plant Sci. 172: 970-977.

Mathew, P.M. and A. Mathew. 1983. Studies on the South Indian Compositae V. Cytotaxonomic consideration of the tribes Vernonieae and Eupatorieae. Cytologia (Tokyo) 48:679690.

McCollum, G.D. 1958. Comparative studies of chromosome pairing in natural and induced tetraploid Dactylis. Chromosoma 9:571-605.

Mecchia, M.A., A. Ochogavía, J.P. Selva, N. Laspina, S. Felitti, L.G. Martelotto, G. Spangenberg, V. Echenique, and S.C. Pessino. 2007. Genome polymorphisms and gene differential expression in a 'back-and-forth' ploidy-altered series of weeping lovegrass (Eragrostis curvula). J. Plant Physiol. 164:1051-1061.

Moscone, E.A., M. Baranyi, I. Ebert, J. Greilhuber, F. Ehrendorfer, and A.T. Hunziker. 2003. Analysis of nuclear DNA content in Capsicum (Solanaceae) by flow cytometry and feulgen densitometry. Ann. Bot. (Lond.) 92:21-29.

Naranjo, C.A., M.R. Ferrari, A.M. Palmero, and L. Poggio. 1998. Karyotype, DNA content and meiotic behaviour in five South American 
species of Vicia (Fabaceae). Ann. Bot. (Lond.) 82:757-764.

Narasinga Rao, P.S.R.L. and J.V. Pantulu. 1982. Fertility and meiotic chromosome behavior in autotetraploid pearl millet. Theor. Appl. Genet. 62:345-351.

Ozkan, H., A. Levy, and M. Feldman. 2001. Allopolyploidy-induced rapid genome evolution in the wheat (Aegilops-Triticum) group. Trends Genet. 19:141-147.

Pecinka, A., P. Suchánková, M. Lysak, B. Trávníček, and J. Doležel. 2006. Nuclear DNA variation among several Central European Koeleria taxa. Ann. Bot. (Lond.) 98:117122.

Petrov, D. 2001. Evolution of genome size: New approaches to an old problem. Trends Genet. 19:141-147.

Poggio, L., G. Gonzáles, and C.A. Naranjo. 2007. Chromosome studies in Hippeastrum (Amaryllidaceae): Variation in genome size. Bot. J. Linn. Soc. 155:171-178.

Pringle, G.J. and B.G. Murray. 1993. Karyotypes and C-banding patterns in species of Cyphomandra Mart. ex Sendtner (Solanaceae). Bot. J. Linn. Soc. 111:331-342.

Rabakonandrianina, E. and G.D. Carr. 1987. Chromosome numbers of Madagascar plants. Ann. Mo. Bot. Gard. 74:123-125.

Raina, S.N., A. Parida, K.K. Koul, S.S. Salimath, M.S. Bisht, V. Raja, and T.N. Khostoo. 1994. Associated chromosomal DNA changes in polyploids. Genome 37:560-564.

Raina, S.N. and H. Rees. 1983. DNA variation between and within chromosome com- plements of Vicia species. Heredity 51:335346.

Rees, H. 1984. Nuclear DNA variation and the homology of chromosomes. In: Grant, W.F. (ed.). Plant biosystematics. Academic Press, Toronto, Canada.

Reeves, A. 2001. MicroMeasure: A new computer program for the collection and analysis of cytogenetic data. Genome 44:439-443.

Robinson, H. 1999a. Generic and subtribal classification of American Vernonieae. Smithsonian Contrib. Bot. 89:1-16.

Robinson, H. 1999b. Revision of paleotropical Vernonieae (Asteraceae). Proc. Biol. Soc. Washington (USA) 112:220-247.

Robinson, H. 1999c. Two new subtribes, Stokesiinae and Pacourininae, of the Vernonieae (Asteraceae). Proc. Biol. Soc. Wash. 112:216-219.

Robinson, H. 2007. Vernonieal. In: Kadereit, J. and C. Jeffery (eds.). Asterales. The families and genera of vascular plants, Vol. 8 (K. Kubitzki, Series Ed.). Springer, Berlin, Germany.

Romero Zarco, C. 1986. A new method for estimating karyotype asymmetry. Taxon 35:526-530.

Ruas, P.M., C.F. Ruas, A.O.S. Vieira, N.I. Matzenbacher, and N.S. Martins. 1991. Cytogenetics of genus Vernonia Schreber (Compositae). Cytologia (Tokyo) 56:239-247.

Santos, J.L., D. Alfarao, E. Sanchez-Moran, S.J. Armstrong, F.C.H. Franklin, and G.H. Jones. 2003. Partial diploidization of meiosis in autotetraploid Arabidopsis thaliana. Genetics 165:1533-1540.

Shaked, H., K. Kashkush, H. Ozkan, M. Feldman, and A.A. Levy. 2001. Sequence elimination and cytosine methylation are rapid and reproducible responses of the genome to wide hybridization and allopolyploid wheat. Plant Cell 13:1749-1759.

Smith, G.L. and S.B. Jones, Jr. 1987. Cytotaxonomic studies of Piptocarpha subgenus Hypericoides (Compositae: Vernoniea). Rhodora 89:35-40.

Song, K.M., P. Lu, K.L. Tang, and T.C. Osborn. 1995. Rapid genome change in synthetic polyploids of Brassica and its implications for polyploid evolution. Proc. Natl. Acad. Sci. USA 92:7719-7723.

Srivastava, S. and U.C. Lavania. 1991. Evolutionary DNA variation in Papaver. Genome 34: 763-768.

Swaminathan, M.S. and K. Sulbha. 1959. Multivalent frequency and seed fertility in raw and evolved tetraploids of Brassica campestris var. toria. Plant Breeding 90:385 392.

Tate, J.A., D.E. Soltis, and P.S. Soltis. 2005. Polyploidy in plants, p. 372-414. In: Gregory, T.R. (ed.). The evolution of the genome. Elsevier, Amsterdam, The Netherlands.

Torrell, M. and J. Vallès. 2001. Genome size in 21 Artemisia L. species (Asteraceae, Anthemideae): Systematic, evolutionary and ecological implications. Genome 44:231-238.

Wendel, J.F. 2000. Genome evolution in polyploids. Plant Mol. Biol. 42:225-249.

Wendel, J.F., R.C. Cronn, J.S. Johnston, and H.J. Price. 2002. Feast and famine in plant genomes. Genetica 115:37-47. 